\title{
Marketing cost, marketing margin and price spread of soybean in Parbhani district of Maharashtra
}

\section{S.H. CHAVHAL, J.L. KATKADE, P.U. KAUTHEKAR, R.V. CHAVAN AND L.S. SUDEWAD}

Received : 18.08.2014; Revised : 30.08.2014; Accepted : 18.09.2014

\begin{abstract}
The investigation was made to know the marketing cost, marketing margin and price spread in soybean. The study was conducted in the Parbhani market for surveying of 30 market intermediaries. Three marketing channel were noticed in sale of soybean viz., Producer-Village merchant-Wholesaler- Oil processor (channel-I), Producer-Wholesaler- Oil processor (channel-II), Producer- Oil processor (channel-III), It was observed that per quintalmarketing cost was higher in channel-I i.e. Rs. 169.69 followed by Rs. 138.65 in channel-II and Rs.38.80 in channel-III, respectively. Producer's share in consumer's rupee was maximum in channel-III (98.93 \%) while minimum in channel-I $(83.14 \%)$.
\end{abstract}

KEY WORDS : Soybean, Marketing cost, Marketing margin, Price spread

How to cite this paper : Chavhal, S.H., Katkade, J.L., Kauthekar, P.U., Chavan, R.V. and Sudewad, L.S. (2014). Marketing cost, marketing margin and price spread of soybean in Parbhani district of Maharashtra. Internat. J. Com. \& Bus. Manage., 7(2) : 334-337.

\section{MEMBERS OF THE RESEARCH FORUM}

Correspondence to:

S.H. CHAVHAL, Department of Agricultural Economics, College of Agriculture, Vasantrao Naik Marathwada Krishi Vidyapeeth, PARBHANI (M.S.) INDIA

Authors' affiliations:

J.L. KATKADE, P.U. KAUTHEKAR, R.V. CHAVAN AND L.S. SUDEWAD, Department of Agricultural Economics, Vasantrao Naik Marathwada Krishi Vidyapeeth, PARBHANI (M.S.) INDIA 